\title{
A Study of Consumer Awareness towards e-Banking
}

\section{Amutha D*}

Department of Economics, St. Mary's College, Tuticorin, India

\begin{abstract}
The paper deals the consumers perception towards e-banking system related to consumer awareness towards e-banking system with special reference to Tuticorin District of Tamilnadu. Data for this investigation were collected from primary as well as secondary sources. The sampling is random. The data was collected during the months between April to June, 2015. The data collected from the primary source were analysed with the help of various statistical measures such as simple percentage analysis, averages, F-Statistic, chi square test and probability analysis were used. Secondary data have been collected from books, journals, newspapers, internet and periodicals. It is inferred that $36.67 \%$ of the respondents income levels are up to Rs. $1,00,000,52.22 \%$ of the respondents are Rs. $1,00,001$ to Rs. $3,00,000$ and $11.11 \%$ respondents are belonging to above Rs. $3,00,000$ and the average income is 167222 . The study reveals that, the opinion of customers on future expectations. Out of the total respondents, Majority (i.e.) $58.89 \%$ of the sample respondents have mentioned that they would like operate their banking transactions in a core banking environment which is free from neither technical intervention such as computer connecting nor $23.33 \%$ of the samples respondents expect the bank will provide security. $17.78 \%$ of the sample respondents have stated reasonable charges have to be imposed on their banking transaction. The main difficulty for using the E-banking facility is less knowledge about the operations of banking facility ( $50 \%)$. Respondents also feel the services of E-banking too complex to use (30\%) and respondents also believe the E-banking to be risky $(12.22 \%)$. The research report is based on primary data. According to the study, the researcher concludes that the most of the bank customers are aware about all the banking services in Tuticorin District of Tamilnadu. The banks further have to take necessary steps to educate the customers regarding the new technology and other services offered by the banks.
\end{abstract}

Keywords: Electronic banking; Internet banking; Credit/debit cards; Transparency; Accuracy; Cost saving; Customer's awareness and Satisfaction

\section{Introduction}

The Internet has changed the operations of many businesses, and has been becoming a powerful channel for business marketing and communication American Banker [1]. The banking industry has followed this trend in recent years, and sometimes called "e-banking" referring to all banking transactions now completing through Internet applications $[2,3]$. The advance of communication and computer technology and the availability of the Internet have made it possible that one can do most banking transactions from a remote location even without stepping into a physical financial structure i.e., the emerging of e-banking Bruene [4]. Today, less than $30 \%$ of the same consumer financial transactions run through a branch office or the lobby of a main bank office (Online Banking Report. As a result, the banks, as an industry, are formulating strategic plans to fight back in winning their customers suggested by Healy [5].

E-banking has been viewed as an advanced upgrading from previous electronic delivery systems to open many new business opportunities for the banking industry [6]. A survey revealed that at that time there was a planned $\$ 2$ billion new investment in the new electronic banking technology within the banking industry Radeki [7]. Among surveyed banks at the time, about two third (66\%) planned to invest in telephone banking technology, and the remaining one third (34\%) already targeted e-banking options. Some key issues addressed in the recent literature about the e banking include: customer acceptance and satisfaction, services rendered, value added for consumers and banks, privacy concerns, profitability, operational risks, and competition from non-banking institutions Boss et al. [8]. In addition to previous electronic banking delivery systems-automated teller machine (ATMs) and telephone transaction processing centers, online banking provides banks a new and more efficient electronic delivery tool Costanzo [9]. There have been several major challenges and issues faced to the e-banking growth and the e-business in general. One major obstacle addressed most is the security concern $[10,11]$. Another issue challenged e-business (including e-banking) is the quality of delivery service-including both delivery speed (i.e., short advance time required in ordering) and delivery reliability i.e., delivery of items/services on time Furst et al. [12]. Limited payment options available to online customers are also being complained by Furash, [13]. Additionally, customers (who are non-computer "genius" like most senior citizens) have been reluctant in their choice of doing business (including banking transactions) online and worried their unfamiliarity about the computer placing them in a disadvantageous position [14]. The paper deals the consumers perception towards e-banking system related to consumer awareness towards e-banking system with special reference to Tuticorin District of Tamilnadu.

\section{Objectives}

1. To know the socio economic characteristics of the customers of E-banks

2. To identify the reasons for preferring E-banking.

3. To study the consumer's service quality in E-banking System.

4. To find out the opinion of the respondents regarding the various problems of E-banking

5. To give valuable suggestions to improve awareness and satisfaction about E-banking services.

*Corresponding author: Amutha D, Associate. Professor of Economics, St. Mary's College, Tuticorin, India, E-mail: amuthajoe@gmail.com

Received May 17, 2016; Accepted June 10, 2016; Published June 13, 2016

Citation: Amutha D (2016) A Study of Consumer Awareness towards e-Banking Int J Econ Manag Sci 5: 350. doi:10.4172/2162-6359.1000350

Copyright: (c) 2016 Amutha D. This is an open-access article distributed under the terms of the Creative Commons Attribution License, which permits unrestricted use, distribution, and reproduction in any medium, provided the original author and source are credited. 


\section{Research Methodology}

The study is intended to cover the awareness and satisfaction about E-banking facility provided by commercial banks in Tuticorin district of Tamilnadu. Data for this investigation were collected from primary as well as secondary sources. The sample chosen consisted of 90 sample respondents representing the customers of E-banks. The sampling is random. The data was collected during the months between April to June, 2015. The data collected from the primary source were analysed with the help of various statistical measures such as simple percentage analysis, averages, F-Statistic, chi square test and probability analysis were used. Secondary data have been collected from books, journals, newspapers, internet and periodicals (Table 1).

\section{Results and Discussion}

From the above table it is clear that $40 \%$ of the respondents belong to up to 25 years, $43.33 \%$ of the respondents belong to between $26-50$ years and $16.67 \%$ of the respondents are in the age group of above 50 years and the mean age group is 33.41667 (Table 2). From the above table it is clear $61.11 \%$ of the respondents belong to male group and $38.89 \%$ of the respondents belong to female group (Table 3). From the survey the above table reveals that $64.44 \%$ of the respondents are married and $35.56 \%$ of the respondents are unmarried (Table 4 ). From the above table out of 90 respondents, it is clear that $13.33 \%$ of the respondents are illiterate, $22.22 \%$ of the respondent's educational qualification is school level and $26.67 \%$ of the respondent's educational qualification is college level and $20 \%$ of the respondent's educational qualification is

\begin{tabular}{|c|c|}
\hline Age in Group (in years) & No. of Respondents \\
\hline Up to 25 & $36(40)$ \\
\hline Between $26-50$ & $39(43.33)$ \\
\hline Above 50 & $15(16.67)$ \\
\hline Total & $90(100)$ \\
\hline
\end{tabular}

Table 1: Distribution of sample respondents according to their age. Source: Primary Data. Figures in brackets represent percentages to total.

\begin{tabular}{|c|c|}
\hline Gender & No. of Respondents \\
\hline Male & $55(61.11)$ \\
\hline Female & $35(38.89)$ \\
\hline Total & $90(100)$ \\
\hline
\end{tabular}

Table 2: Distribution of sample respondents according to their gender. Source: Primary Data. Figures in brackets represent percentages to total.

\begin{tabular}{|c|c|}
\hline Marital Status & No. of Respondents \\
\hline Married & $58(64.44)$ \\
\hline Unmarried & $32(35.56)$ \\
\hline Total & $90(100)$ \\
\hline
\end{tabular}

Table 3: Distribution of sample respondents according to their marital status. Source: Primary Data. Figures in brackets represent percentages to total.

\begin{tabular}{|c|c|}
\hline Educational Qualification & No. of Respondents \\
\hline Illiterate & $12(13.33)$ \\
\hline School level & $20(22.22)$ \\
\hline College level & $24(26.67)$ \\
\hline Professional & $18(20.00)$ \\
\hline Diploma & $16(17.78)$ \\
\hline Total & $90(100)$ \\
\hline
\end{tabular}

Table 4: Distribution of sample respondents according to their educational qualification. Source: Primary Data. Figures in brackets represent percentages to total. professionals and $17.78 \%$ of the respondent's educational qualification is diploma (Table 5). From the above table it is clear that $54.44 \%$ of the occupational status of respondents are belong to employee, $13.33 \%$ of the respondents belonging to business, $8.89 \%$ belonging to agriculture, $12.22 \%$ belong to professional $18.89 \%$ belonging to student (Table 6). From the above table it is inferred that $36.67 \%$ of the respondents income levels are up to Rs. $1,00,000,52.22 \%$ of the respondents are Rs. $1,00,001$ to Rs. 3,00,000 and $11.11 \%$ respondents are belonging to above Rs. 3,00,000 and the average income is 167222 (Table 7). The table highlights the customer preference towards E-banking services. Out of the total respondents, Majority (i.e.) $93.33 \%$ of the customers are satisfied about the mobile banking as most of the customers prefer to adopt the mobile banking services in the near future. $88.89 \%$ of the customers are satisfied with the ATM and $78.89 \%$ of the customers are satisfied about internet banking. $86.67 \%$ of the customers are satisfied about credit/debit cards service and $81.11 \%$ are satisfied about the Electronic fund transfer services by the customer. The chi-square analysis $\left(\chi^{2}=53.1, \mathrm{df}=8, \mathrm{P}=0.000\right)$ result shows there is relationship between the customer preference towards E-banking services and their level of satisfaction. Thus, most of the respondent is aware and satisfied with the services provided by the bankers (Table 8). Easy and convenient access, confidentiality, service quality and time saving are the factors influencing the respondents to prefer e-banking services at $75.56 \%, 55.56 \%, 74.44 \%$ and $81.11 \%$ respectively in Tuticorin district. $70 \%, 54.44 \%, 85.56 \%, 34.44 \%$, and $97.78 \%$ of the respondents are influenced by factors such as transparency, accuracy, cost saving, ubiquity, and speed respectively to prefer e-banking services of the commercial banks. Social status, security, control over funds, time out feature and exchange of information are the motivating factors for the customers at $95.56 \%, 50 \%, 40 \%, 58.89 \%$ and $90 \%$ respectively to prefer

\begin{tabular}{|c|c|}
\hline Occupation & No. of Respondents \\
\hline Employee & $49(54.44)$ \\
\hline Business & $12(13.33)$ \\
\hline Agriculture & $8(8.89)$ \\
\hline Professional & $11(12.22)$ \\
\hline Student & $17(18.89)$ \\
\hline Total & $90(100)$ \\
\hline
\end{tabular}

Table 5: Distribution of sample respondents according to their occupation. Source Primary Data. Figures in brackets represent percentages to total.

\begin{tabular}{|l|c|c|}
\hline Income & No. of Respondents & Percentage \\
\hline Up to Rs. $1,00,000$ & 33 & 36.67 \\
\hline Rs $1,00,001$ to Rs $3,00,000$ & 47 & 52.22 \\
\hline Above Rs 3,00,000 & 10 & 11.11 \\
\hline Total & 90 & 100.00 \\
\hline
\end{tabular}

Table 6: Distribution of sample respondents according to their income. Source: Primary Data.

\begin{tabular}{|c|c|c|c|c|}
\hline Customer preference & Satisfied & Percentage & Not Satisfied & Percentage \\
\hline Mobile Banking & 84 & 93.33 & 6 & 6.67 \\
\hline E-Cheques & 69 & 76.67 & 21 & 23.33 \\
\hline Phone Banking & 61 & 67.78 & 29 & 32.22 \\
\hline Credit /Debit cards & 78 & 86.67 & 12 & 13.33 \\
\hline ATM & 80 & 88.89 & 10 & 11.11 \\
\hline Electronic fund transfer & 73 & 81.11 & 17 & 18.89 \\
\hline Tele banking & 54 & 60 & 36 & 40 \\
\hline Internet Banking & 71 & 78.89 & 19 & 21.11 \\
\hline SMS Banking & 59 & 65.56 & 31 & 34.44 \\
\hline
\end{tabular}

Table 7: Customer preference of E-banking services ( $n=90)$. Source: Primary data. 


\begin{tabular}{|c|c|c|}
\hline Motivating Factors & No. of Respondents & Percentage \\
\hline Time saving & 73 & 81.11 \\
\hline Accuracy & 49 & 54.44 \\
\hline Ubiquity & 31 & 34.44 \\
\hline Easy and convenient access & 68 & 75.56 \\
\hline Cost saving & 77 & 85.56 \\
\hline Transparency & 63 & 70.00 \\
\hline Social status & 86 & 95.56 \\
\hline Confidentiality & 50 & 55.56 \\
\hline Exchange of information & 81 & 90.00 \\
\hline Service quality & 67 & 74.44 \\
\hline Security & 45 & 50.00 \\
\hline Speed & 88 & 97.78 \\
\hline Control over funds & 36 & 40.00 \\
\hline Time out feature & 53 & 58.89 \\
\hline Total & 90 & 100.00 \\
\hline
\end{tabular}

Table 8: Motivating factors to prefer E-banking services $(n=90)$.

\begin{tabular}{|l|c|c|}
\hline Service Quality Factors & $\begin{array}{c}\text { Average Score } \\
\text { Respondents }\end{array}$ & F-Statistic \\
\hline Time factor & 3.1032 & 1.1361 \\
\hline Reliability & 2.1736 & $3.1432^{\star}$ \\
\hline Queue management & 2.1438 & 1.6413 \\
\hline On-line bill payments & 2.3710 & 1.4351 \\
\hline Easy to use and user friendliness & 3.2134 & 0.4751 \\
\hline Anytime and anywhere banking facility & 3.6415 & $3.2185^{\star}$ \\
\hline Convenience way of operating banking transactions & 2.8124 & $3.6141^{*}$ \\
\hline 'Significant at 5\% level. & & \\
\hline
\end{tabular}

Table 9: Customer perception on service quality factors.

e-banking services of the commercial banks in Tuticorin district of Tamilnadu.

\section{Customer Perception on Service Quality Factors}

The convenience of online banking is helping people gain greater control of their finances and contributing to changing patterns in cash withdrawal and day to day money management. [15,16] identified one of the very important service quality dimensions of i-banking service quality is reliability. Saving time is an importance factor which influences the customers prefers to use i-banking [15]. The most popular online transaction through internet banking is funds transfer/ bill payment [15]. Ease of use is another important determinant for the customer preferring the internet banking [15]. Online banking users say that convenience is the most important factor, online banking lets them access their accounts from anywhere and at any time [17]. One among the important dimensions of e-banking service quality is queue management Joseph et al. [18]. The attitude towards the above said customer perception on service quality factors is measured at a five point scale highly satisfied, satisfied, moderate, dissatisfied, highly dissatisfied which carries 5, 4, 3, 2, and 1 mark respectively. The mean score in the attitude towards various customer perceptions on service quality factors are measured by the customers separately is shown in the following table (Table 9). The customers are asked to rate each SQFs five point scale according to their order of satisfaction. The mean score of each SQFs and F-Statistic is given in table. According to the table customer perception on service quality factors was found high in the variables namely reliability, anytime and anywhere banking facility and convenience way of operating banking transactions. The mean score values of these variables are 3.1432, 3.2185 and 3.6141 respectively [19].

\begin{tabular}{|c|c|c|}
\hline Future Expectations & $\begin{array}{c}\text { No. of } \\
\text { Respondents }\end{array}$ & Percentage \\
\hline Reasonable cost & 16 & 17.78 \\
\hline $\begin{array}{c}\text { Expected neither technique intervention nor } \\
\text { quality services }\end{array}$ & 53 & 58.89 \\
\hline Security & 21 & 23.33 \\
\hline Total & 90 & 100.00 \\
\hline
\end{tabular}

Table 10: Respondent's response with future expectations with E- banking services.

\begin{tabular}{|c|c|c|}
\hline Difficulty & No. of Respondents & Percentage \\
\hline Risky & 11 & 12.22 \\
\hline Less Knowledge & 45 & 50 \\
\hline High Fees & 7 & 7.78 \\
\hline Complex to use & 27 & 30 \\
\hline Total & 90 & 100.00 \\
\hline
\end{tabular}

Table 11: Difficulty for using the E-banking facility.

The significant differences among the different customers are noticed in the case of service quality factors namely reliability, anytime and anywhere banking facility and convenience way of operating banking transactions since the respective ' $F$ ' values are significant at 5 per cent level (Table 10). The table reveals that the opinion of customers on future expectations. Out of the total respondents, Majority (i.e.) $58.89 \%$ of the sample respondents have mentioned that they would like operate their banking transactions in a core banking environment which is free from neither technical intervention such as computer connecting nor $23.33 \%$ of the samples respondents expect the bank will provide security. $17.78 \%$ of the sample respondents have stated reasonable charges have to be imposed on their banking transaction (Table 11). The main difficulty for using the E-banking facility is less knowledge about the operations of banking facility (50\%). Respondents also feel the services of E-banking too complex to use (30\%) and respondents also believe the E-banking to be risky (12.22\%).

\section{Conclusions}

The research report is based on primary data. According to the study, the researcher concludes that the most of the bank customers are aware about all the banking services in Tuticorin District of Tamilnadu. The banks further have to take necessary steps to educate the customers regarding the new technology and other services offered by the banks. Banks may extend customer meeting time with bank officials and also friendly approach is necessary. Definitely it will help to retain the existing customers and to attract new customers. It will automatically improve the banking service and development of banks in India and also in abroad. The research report is useful to know the consumer awareness of e-banking system and what types of risk involved in e-banking system.

\section{References}

1. American Banker (2000) Web Banks Beat Branches on Ratios but there's No Competition.

2. Beer Stan (2006) Customers Preference on Internet Banking Survey.

3. Kevin B (2001) Has dot.com Banking Peaked? ABA Banking Journal. pp: 73-75.

4. Boss S, McGranahan D, Mehta A (2000) Will the Banks Control Online Banking? The McKinsey Quarterly.

5. Jim B (2002) Online Banking by the Numbers.

6. Chris C (2000) Pioneer Internet-Only Bank Has a new Strategy. American Banker, p: I. 
7. Tom E (2001) The Economics of Online Banking. Target Marketing. February, p: 67.

8. Feinman T, Goldman D, Wong R, Cooper N (1999) Security Basics: A Whitepaper.

9. Financial Services Security Lab Background (2001) Security Issues and Threats. Banking Industry Technology Secretariat.

10. Fugazy, Danielle (2002) Banking: Online Banking: To Be or Not To Be. Web Finance.

11. Furash, Edward E (1994) Payments system under siege: customers want information along with monetary transfers, non-banks are providing it. ABA Banking Journal, Vol-86, p: 55.

12. Furst K, Lang WW, Nolle DE (2000) Internet Banking: Developments and Prospects. Office of the Comptroller of the Currency.
13. Healy, Thomas J (1999) Why You Should Retain Your Customers. America's Community Banker. p: 22.

14. IAMAl's Report on Online Banking (2006).

15. Johnson JR (1999) Raising relationships: the art and science of connecting with customers. Bank Marketing, p: 16.

16. Joseph M, McClure C, Joseph B (1999) Service Quality in Banking Sector: The Impact of Technology on Service Delivery. International Journal of Bank Marketing, 17: 182-191.

17. Jun M, Cai S (2001) The key Determinants of Internet Bank Service Quality: a Content Analysis. International Journal of Bank Marketing, 19: 276-291.

18. Online Banking Report (2009) Internet Strategies for Financial Institutions.

19. Radecki LJ, Wenninger J, Orlow DK (1997) Industry structure: electronic delivery's potential effects on retail banking. Journal of Retail Banking Services, Vol-19, p: 57. 